\title{
Dark Places: The Movement of the Image \\ (Thoughts on the work of Veronica Brady)
}

\author{
Gail Jones \\ University of Western Sydney \\ gail.jones@westernsydney.edu.au
}

\begin{abstract}
Copyright@2017 Gail Jones. This text may be archived and redistributed both in electronic form and in hard copy, provided that the author and journal are properly cited and no fee is charged, in accordance with our Creative Commons Licence.
\end{abstract}

(i)

Fra Angelico's painting, Pious Women at the Tomb (1440), depicts four tragically bewildered women looking for the absent body of Christ. One holds her hand at her brow like an explorer, and is peering down into his marble casket as into a vastly deep well. Three others stand by, sadly dumfounded. Behind the women, floating in air, is an image of the risen Christ, autonomous, autotelic, blazing in a mystical disc. But the women all look the wrong way and are left bereft. An angel points to the vision, but still their gaze is misdirected. A Dominican monk kneels in reverence before the empty space; a passage of gospel script instructs as to the correct sign to read; still, the four women stare into darkness.

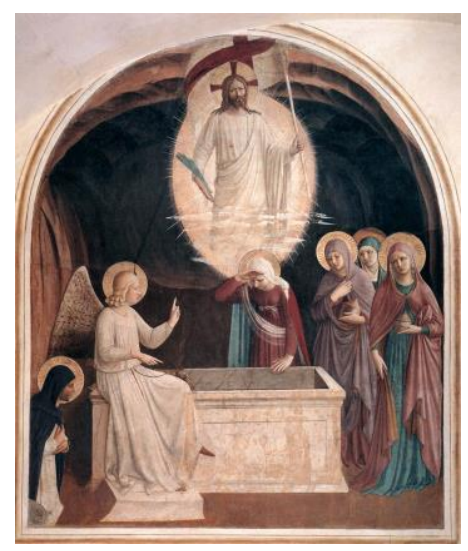

The image, one might say, is essentially of mistake: of assuming emptiness and absence, and of missing meaning. The image asks, what is the remainder of any death? How might secure significance be made? What signs offer consolation; what immaterially might make sense?

Bruno Latour uses this image, among others, to make a distinction between idolatry and iconophilia: idolatry he defines as giving entire attention to the visual, as if this might offer unmediated access to the truth; iconophilia, on the other hand, "respects ... not the image, but the movement of the image"; it respects "the series of transformations for 
which each image is only a provisional frame" (Latour 1998, pp 418-430, p 421; Miller 2013). This distinction is relevant beyond the art-historical: it is an example of including what we might call an 'inferred' dimension, generously and openly, in all forms of knowledge - in science, philosophy, art and social theory. Science, in particular, can learn from art. Latour recommends "multiplying mediators", so that in our understandings, as in our readings of paintings, we consider movements of disembodiment and reembodiment, we imagine competing vectors in the construction of meaning, we admit the non-realist and inexact qualities in all things. Latour uses obdurate terms like "information transfer" to describe the circuitry of Fra, but he's moved by its indirection and complication, and believes too that these are the basis for reconstructing an open model of knowledge. The woman with her hand to her brow, peering into enigma, is emblematic of the limit of material - let us say, positivist - signs; yet also human, deeply human, in the intensity of her searching.

(ii)

Iconophilic in Bruno Latour's sense, much of Veronica Brady's intellectual life worked with the principles of Fra Angelico's vision: the negotiation of puzzled being, the deep mystery of invisible presence, the ways in which art speaks in oblique and multiple registers. Peering into the darkness. Intuiting, not seeing directly. The human condition of stranded yearning after unverifiable transcendence.

Veronica spoke robustly of "the idol of the answer". She considered questions to be much more important than answers and her manner, though often publically hyperdeclarative, was more privately, and more secretly, interrogative. When she chose her name as a Loreto sister - Veronica - the attraction was in part to a flimsy, even uncertain vision, and the idea of bearing of witness to physical suffering. She disdained sentimentalism, but was engaged by the charm of imagery. And in her own case, the idea of contact with the holy that was at once physical and metaphysical. The trace, a notion she loved, seemed to her to say something essential about how we apprehend mystery and are in a necessary relation of existential humility to the larger dramas of the world.

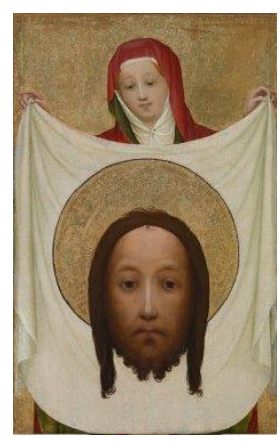

The so-called 'Master of Saint Veronica' produced this image in about 1420, 'St Veronica and the Sudarium', showing a modest and lovely woman holding up a gigantic Christ head on a veil. Now in the National Gallery in London, I lodge on this painting among the many perhaps because its proportions are so endearingly odd and its saint's face so endearingly distinctive. 
(iii)

Veronica Brady's heterodoxy centred on the trace. The undoing of certainty, kenosis as a mode of knowing: these were the cherished principles of her own version of faith. Her commitment to Australian literature was defined by essentially religious questions - but not doctrinally so (indeed she was ferociously anti-doctrinal), rather by the manner in which imaginative life produces and contemplates images of being and nothingness. Drawn to the symbolic, she was devoted in particular to the work of Patrick White, whom she held to be sui generis (her term) and paradigmatic.

The material/immaterial nexus, so central to White's imagining, was for Veronica Brady a touchstone to her own theology. She spoke sincerely of his work as a 'theological training', even as she described the writer himself as cranky, mischievous and sometimes perversely cruel. Further, she wrote of White as engaged in 'saintly' narrative and like the Jewish theologian Edith Wyschogrod, a congenial influence in her later years, the heuristic terms narrativity, corporeality, textuality and historicality were the basis for reading as moral philosophy (1990, p.5). Citing both Saints and Postmodernism and An Ethics of Remembering ${ }^{2}$, she found in these books an eclecticism not unlike her own, and a philosophical preoccupation with similar themes.

The central concern was antique and inveterate: the question of literature as a vehicle for spiritual values. But so too, and crucially, was the matter of ideology. In Australia Veronica Brady was a public figure of leftist politics and a fearless activist, aware of the economy within which power accrues to the privileged and the wealthy. Her sympathies were radical, with the disenfranchised, the dispossessed, the neglected and the suffering; and religious vocation was the ineluctable centre of her values. Liberation theology, Simone Weil, the work of philosophers who dealt with the idea that meaning might be beyond fixity (like Derrida), ${ }^{3}$ her Nietzschean conviction that present age requires a "transvaluation of values" 4 - these were the essential fixtures of her intellectual life. How valiant a thinker, and how principled. How bold and impertinent in her hermeneutical heterogeneity. I'm reminded here of Roland Barthes: "the critic does not ask to be granted a 'vision' or a 'style', but only to be granted the right to a certain discourse, which is an indirect discourse." (1972, p. xii). Those who knew Veronica hear her voice in her prose and recognize the strenuous practice of a particular discourse. She possessed key terms and notions; but was always alert to new theories and difficult ideas, so that the epistemological grounds of her argument were flexible, variable and sometimes also a little vague.

Veronica's championing of the cause of indigenous Australians (and their literature) is well known ${ }^{5}$. Apart from the wish to honour and make known Aboriginal writing, she wanted also to accuse, to express dismay, and to insist on white culpability. Settler Australia, she maintained, was constitutively racist and founded on an anxious drama of psychogeography:

The way most settlers then and now chose to deal with it [frontier violence], was to deny their situation and repress any sense of guilt, projecting it instead outwards, onto their victims. In this way ... the Aborigine came to be figured as the Wild Man, the embodiment not only of all that is savage, that is uncivilized, but also evil. Psychologically, this projection was helpful. After the trauma of leaving home and the long, difficult and dangerous voyage and, 
faced with an equally difficult and dangerous environment, the precise content of their own humanity no longer seemed clear. But at least they could assure themselves they were "not like that", like the Aborigines. (Burderlean 2007, p. 128)

Versions of this argument appear throughout her work. Most telling here is the phrase "Psychologically, this projection was useful". Indebted initially to Jung (whom she later repudiated), she relied mostly on a naturalized Freudian lexicon - repression, projection, sublimation; also the use-value, as it were, of certain forms of displacement. Unusually perhaps for a Catholic thinker, she also located evil in self-interested projection and alienation and deplored the cultural capital possessed by those whom, with a wry and canny smile, she liked to call 'the pseudo-religious'. Her models were White's characters - the banal and platitudinous Mrs Flack and Mrs Jolly from Riders in the Chariot, Mr and Mrs Merrivale in The Fringe of Leaves; the smugly ignorant Mr Bonner in Voss (Brady 2005). Bonner, the financier of Voss's journey, was a man who "was inclined to jingle his money in his pocket, for fear that he might find himself still apprenticed to the past" (p.17); this tiny detail also draws attention to the allegiance of capitalism and colonialism and the deathly fetish of money Veronica saw everywhere in action. One of her articles was entitled "Polyphonies of Self" (1994, pp. 30-37); the metaphor of White's autopoesis of faceted flaws is referenced here; likewise her belief that monoculture is fascistic and that self must be grounded in multiplicity. She was fond of quoting particular passages which made clear the false consciousness and anxiety of those who are spiritually afraid:

Safe in life, safe in death, the merchant [Bonner] liked to feel. In consequence, he had often tried to calculate, for how much and from whom, salvation might be bought and, to ensure his last entrance would be made through the last cedar door, had begun in secret to subscribe liberal sums to all denominations, including those of which he approved. (p.349)

Mystery is that which is incalculable and which has no profit, or sum. Convinced of the Manichean allegory (JanMohamed 1983), Veronica saw in White's satirical portrait of colonial mentality a broader social diagnosis of mistaken value. Those who see only material signs are stranded in a depleted symbolic order.



(iv) 
Against status, wealth, the comfortable life, Veronica recommended spiritual and intellectual 'discomfort'. Although she called herself a 'social-materialist', she believed the immaterial, generally speaking, to have vital energy and agency and was enthralled to both the eschatological and mystical promise of the numinous. Materiality itself depends on invisible entities, of which consciousness, the innerness that incessantly moves outward, is the human sign; and mysticism is the glorious possibility of transcendental semiosis. Theologically, it is interception that defines the link. Not will. Not desire. Not spiritual practice or enterprise. Veronica often cited David Marr's account of Patrick White's fall into the muck on his farm at Castle Hill, cursing the God he did not believe in then being "interrupted ... by a grandeur too overwhelming to express" (2003, p. 153). Loss of freedom, abjection, unconcealment, a crucially transvaluing shift in scale: these were the forms of a true epiphany. In the via negativa tradition to which Veronica was allied, it was Stan Parker's loneliness at the end of The Tree of Man, during which he spits into the dirt at the feet of an evangelist, the convoluted suffering of the four elect outcasts in Riders in the Chariot, Elizabeth Hunter's Lear-like unmaking and dissolution in The Eye of the Storm, that offered moments of philosophical instruction. One might say these were the icons of her Australian model of faith. "In White's work," she wrote, "discomfort rather than comfort is the sign of God's presence." (2003, p. 153) That she matched her Christian sensibility to his image repertoire does not mean she was wholly uncritical; but certainly, she considered White a theologian-in-narrative.

Even more than discomfort, Veronica believed in what she nominated 'the darkness of God.' If one must simply endure, and wait on interception, then religion, like interpretation, must submit to contingency and over-determined possibility. She was among the first critics to notice how profoundly White's writing relied on images of light and darkness. Writing on Ellen Roxburgh, captive of Aborigines in colonial Australia in The Fringe of Leaves, she suggests:

Women perhaps know more of this darkness, bodily as well as socially ... Women's bodily existence makes us more aware of our own finitude and of our subjection to physical necessity, more aware of the need for the descent into the darkness of life if new life is to emerge. (2003, p. 157)

Veronica has in mind here the moment of Ellen's cannibalism, constructed through motifs of communion and sanctification. That she endorses White's wish to make holiness of necessity is entirely within the frame they mutually recommend, an insistence that 'civilization' has a shadow side that might be the route to other forms of being and knowing. Careful to avoid primitivism or some 'use-value' casting of Aboriginal Australians into spiritual guides, both the critic and the writer risk the insidious implication that abjection is finally the measure of self-realization -or what has been identified as the supplanting of indigenous rights and presence with that of the "white indigene'. ${ }^{6}$ What is interesting is the degree to which both are in concord; unfashionable spiritualism informs White's and Brady's vision of Australian meaning and neither resile from its vigorous defence. In part this was a critique of Australian secularism:

Religion, it seems, is a scandal that refuses to go away, even in the most secular of societies ... the impulse continues and must be acknowledged and lived through, especially perhaps in a secular society since it has to do with negative and midliminal experience... as common to the unbeliever as the believer. $^{7}$ 
Unbelievers and believers alike are subject to the 'impulse' to recognize and assess 'negative' experience. When Veronica Brady located her own search in the field of Australian literary studies, she sought to affirm the study of language and narrative - and the movement of images - as an endeavour that might, with due humility, enter and know fields of darkness.

There are no adequate summaries of the lives or thoughts of others. There are no accounts possible of the histories of our deepest affections. Those we love remain illimitable, like the sky beyond the window. And inadequation (the non-realist, the inexact) is also the condition of bereavement: words are spoken, memories rehearsed, there are exchanges of sorts, there are even modest retrievals and small confirmations - 'yes, I remember, yes, she once said that' - but the lost are always beyond, becoming stylized as we speak of them.

So it is the poetic, more properly poesis, to which I turn. Veronica adored poetry, above all that of Francis Webb, Judith Wright, Rainer Maria Rilke and Wallace Stevens. A few lines of Stevens come to mind:

Here, now, we forget each other and ourselves.

We feel the obscurity of an order, a whole,

A knowledge, that which arranged the rendezvous.

Within its vital boundary, in the mind.

We say God and the imagination are one...

How high that highest candle lights the dark. (1982, p. 524)

For Veronica the idea that God is also the faculty of imagination is not sacreligious, nor does it discount what she thought of as the utter alterity of her God. Another kind of modernist, Stevens considers the gentle, 'intensest rendezvous', not interception or interruption. Wallace's speaking voice is located in the calm repose of the dim room at dusk, feeling 'the obscurity of an order', apprehending settling presences; Veronica is equally attracted to a rougher vision and one emphatically local. There's another kind of indwelling and transfiguration - in the natural world, and in disorder. In The Fringe of Leaves we find this moment:

There was once an occasion when she fell down, scattering skywards a cloud of ashen parrots. She would have continued lying on the ground and perhaps become her true self: once the flesh melts, and the skeleton inside it is blessed with its final articulate white, amongst the stone, beneath the hard sky, in this country to which it can at last belong. (p. 281)

All shadows are black. All bones are white. This is holy whiteness, 'the final articulate white' of death. As far as I know Veronica never commented on this moment in her favourite novel. But it seems to me an apposite point at which to conclude the imagining of her imagining, and the giving of honour to her important, still-persisting work. 


\section{Images:}

(i) Fra Angelico 1440. Pious Women at the Tomb, retrieved from: https://upload.wikimedia.org/wikipedia/commons/f/fa/Fra_Angelico__Resurrection_of_Christ_and_Women_at the_Tomb_(Cell_8)_-_WGA00542.jpg

(ii) Master of Saint Veronica (ca. 1395-1415). Saint Veronica with the Sudarium, retrieved from: https://www.nationalgallery.org.uk/paintings/master-of-saintveronica-saint-veronica-with-the-sudarium

(iii) Caption: Patrick White wearing the wooden cross Veronica had given him, retrieved from: https://meanjin.com.au/wp-content/uploads/2015/06/Screen-Shot2015-06-22-at-3.29.27-pm-e1434951043718.png

\section{Works cited:}

Barthes, Roland 1972. Preface, in Critical Essays, trans. R. Howard. Evanston, IL: Northwestern University Press.

Brady, Veronica 1994. Caught in the Draught: On Contemporary Australian Culture and Society. Sydney: Angus and Robertson.

--- 2003. 'A Grandeur Too Overwhelming to Express: Patrick White's Vision of God', in David Neville and Phillip Matthews, eds., Faith and Freedom: Christian Ethics in a Pluralist Culture. Adelaide: Australian Theological Forum Press 2003) p153.

--- 2005. 'God, History and Patrick White', Antipodes, vol. 19, no. 2, Special Issue: The Sacred in Australian Literature, pp. 172-176.

Buderlean, Alma 2007. Otherness in the Novels of Patrick White. Frankfurt: Peter Lang.

Caputo, John D. 1997. The Tears and Prayers of Jacques Derrida: Religion without Religion. Bloomington, IN: Indiana University Press.

Griffiths, Gareth 2009. 'Open Spaces, Contested Places: Writing and the Fundamentalist Inscription of Territory', in A. Stähler and K. Stierstorfer, eds. Writing Fundamentalism. Newcastle: Cambridge Scholars Publishing, pp. 55-76.

Hansson, Karin 1984. 'The Indigenous and the Metropolitan in A Fringe of Leaves', World Literature Written in English, vol. 24, no. 1, pp. 178-189.

Ingram, Penelope 2001. 'Racializing Babylon: Settler Whiteness and the "New Racism", New Literary History, vol. 32, no 1, pp. 157-17.

JanMohamed, Abdul R. 1983. Manichean Aesthetics: the Politics of Literature in Colonial Africa. Amherst, MA: University of Massachusetts Press.

Latour, Bruno 1998. How to be Iconophilic in Art, Science and Religion, in Peter Gallison and Caroline A. Jones, eds., Picturing Science, Producing Art. Hove, UK: Psychology Press, pp. 418-430; p. 421. 
Miller, Adam S. 2013. Speculative Grace: Bruno Latour and Object Orientated Theology. New York: Fordham University Press.

O'Neill, Ray J. 2010. 'Moments of Grace and Blessing: Rites and Rituals in the Process of Healing', in E. Burns Coleman and K. White, eds., Medicine, Religion and the Body. Leiden \& Boston: Brill, pp. 147-167.

Schaffer, Kay 1995. In the Wake of First Contact: the Eliza Fraser Stories. Cambridge: Cambridge University Press.

Stevens, Wallace 1982. 'Final Soliloquy of the Eternal Paramour', Wallace Stevens: The Collected Poems. New York: Vintage, p. 524.

White, Patrick 1983 (1957). Voss. London: Penguin.

--- 1987 (1976). A Fringe of Leaves. London: Penguin.

Wyschogrod, Edith 1990. Saints and Postmodernism: Revisioning Moral Philosophy. Chicago: Chicago University Press, p. 5.

Wyschogrod, Edith 1998. An Ethics of Remembering: History, Heterology and the Nameless Others. Chicago: Chicago University Press.

\footnotetext{
${ }^{1}$ I was reminded of this phrase when I saw Veronica cited in Gareth Griffiths' 'Open Spaces, Contested Places: Writing and the Fundamentalist Inscription of Territory' (2009, p 58).

${ }^{2}$ Wyschgorod was a scholar principally of Levinas, but also dealt with many other thinkers, Heidegger, Derrida, Delueze and Sloterdijik among them, and connected themes of alterity, catastrophe and the need for regeneration of the spirit.

${ }^{3}$ John D. Caputo's The Tears and Prayers of Jacques Derrida: Religion without Religion was one of Veronica's favourite books. ${ }^{4}$ This was her often used phrase. Veronica agreed with Nietzsche's critique of institutional Christianity as
in some ways decadent, corrupt and in need of reform.

${ }^{5}$ See for example the essays in her Caught in the Draught: On Contemporary Australian Culture and Society (1994). This volume includes essays on Mabo, Bill Neidjie, and indigenous writing more generally.

${ }^{6}$ See also Kay Schaffer's careful point-of-view analysis of the indigene in A Fringe of Leaves in In the Wake of First Contact: the Eliza Fraser Stories (1995).

${ }^{7}$ Veronica Brady in Caught in the Draught: On Contemporary Australian Culture and Society, cited in Ray J. O'Neill's 'Moments of Grace and Blessing: Rites and Rituals in the Process of Healing' (BurnsColeman and White 2010, pp. 149).
}

\section{Bio note:}

Gail Jones is a novelist and short story writer and teaches at the University of Western Sydney. She is the author of two collections of short stories and six novels - the last one, A Guide to Berlin, was published recently. Three times shortlisted for the Miles Franklin Award, her books have won numerous literary awards: the Nita B. Kibble Award and the Fiction Prize in the Western Australia Premier's Book Awards with her first novel. Then she was in the longlist for the Man Booker Prize in 2004 with Sixty Lights and was longlisted in two occasions for the Orange Prize. She also was shortlisted for the 
Coolabah, No.22, 2017, ISSN 1988-5946, Observatori: Centre d'Estudis Australians / Australian Studies Centre, Universitat de Barcelona

International IMPAC Dublin Literary Award, the Victorian Premier's Literary Award and the NSW Premier's Literary Award. 